\title{
Reaction in Politics
}

\author{
James Alexander \\ Dept. of Political Science, Bilkent University, Ankara, Turkey \\ jalexand@bilkent.edu.tr
}

\begin{abstract}
Reaction is a subject usually avoided by political theorists, since it raises awkward historical, philosophical and political questions. Perhaps philosophers of history might make better sense of it. In this article I claim that reaction has to be understood in relation to the concepts of revolution, tradition, progress and conservatism. I argue that the specific meaning of reaction is a response to the specific action that establishes the principle that order should be established only on enlightened principles. The few theorists who have dealt with reaction have disagreed about whether it is the same as conservatism or not. I show that reaction is not an element in what I call a status quo conservatism, though it is an element in any conservatism conceived more broadly. I characterise reaction in full as the attempt to reverse the establishment of the principle that only enlightened principles shall be the basis of political order, the attempt to resist the further establishment of those enlightened principles, and also the attempt to criticise contemporary enlightened politics in terms of the unenlightened standards which existed before the revolution.
\end{abstract}

\section{Keywords}

reaction - conservatism - tradition - revolution - progress

\section{Are Conservatism and Reaction the Same or Not?}

Let us begin by considering the question of the relation between conservatism and reaction. Recent studies of reaction divide on this question. Some writers declare that 'reactionaries are conservatives', while others declare that 'reactionaries are not conservatives'. Hardly anyone recognises that this is an antinomy which has to be recognised before anything sensible can be said either 
about the vexed subject of conservatism or about the even more vexed subject of reaction.

The fundamental disagreement can be best expressed by distinguishing the following two positions:

Either: Conservatism is concerned with conserving the status quo, therefore conservatives are not reactionaries.

Or: Conservatism is concerned with conserving more than the status quo, therefore conservatives are reactionaries.

The only point everyone seems to agree on in all the literature on conservatism is that reaction is a bad thing. Some say, in effect, 'reaction is bad, but conservatism is not bad', while others say, 'reaction is bad, and conservatism is also bad'. If we leave the question of its badness to one side for the moment, I think we should be able to recognise that the answer to the question about whether conservatism and reaction are related or not seems to depend on the view one takes of conservatism.

Let me consider both positions in more detail.

The first position is found in many writers. The most famous account is that of Michael Oakeshott. He declared over half a century ago that conservatism 'is not a creed or a doctrine, but a disposition'. This disposition is 'to delight in what is present rather than what was or what may be'. It is worth emphasising this: neither 'what was' nor 'what may be' but 'what is'. The conservative does not want to 'move forwards' or 'move backwards'. The conservative wants to hold onto what he has. This characterisation of conservatism is beguiling. But it is a specific, not general, meaning of conservatism. In this article I shall call it 'status quo conservatism'.

Oakeshott explicitly distinguishes reaction from this sort of conservatism. The conservative is not someone 'last seen swimming against the tide, disregarded not because what he has to say is necessarily false but because it has become irrelevant; outmanoeuvred, not on account of any intrinsic demerit but merely by the flow of circumstance; a faded, timid, nostalgic character, provoking pity as an outcast and contempt as a reactionary'. On the contrary: 'To be conservative is disclosed, not as prejudiced hostility to a "progressive" attitude capable of embracing the whole range of human conduct, but as a disposition exclusively appropriate in a large and significant field of human activity.'

1 Michael Oakeshott, 'On Being Conservative', in Rationalism in Politics and Other Essays ed. Timothy Fuller (Indianapolis: Liberty, 1992), 407-437, at 407-8.

2 Ibid., 415 . 
Something like Oakeshott's definition has been adopted in many places. Anthony Quinton claimed that 'a conservative proper is not a reactionary'. And Roger Scruton, in his Dictionary of Political Thought, defined conservatism as 'a desire to conserve existing things, held to be either good in themselves, or better than the likely alternatives, or at least safe, familiar, and the objects of trust and affection'.4 A reactionary was defined as 'anyone who opposes changes that the left desires, or who seeks to re-establish a political order that has been overthrown in the name of left-wing ideals'. Scruton continued: 'The implication is usually that such a one merely "reacts" to change, and does not initiate change, so that he has no claim to be heard.... ${ }^{5}$ Like Oakeshott, Scruton simply distinguished conservation and reaction, and did so by making conservatism uncontroversial while allowing reaction to remain controversial. The same distinctions more recently have been found in the writings of Kieron O'Hara and Martin Beckstein, ${ }^{6}$ and most recently in Mark Lilla's book on reaction where he says, bluntly, 'Reactionaries are not conservatives.'7

Anyone reading these authors would think there was nothing more to be said. They do not recognise the counter-argument. Yet this is to ignore much common usage in which reaction and conservatism are considered aspects of the same thing. In a book entitled Conservatism in Europe 1770-1945: Traditionalism, Reaction and Counter-Revolution, John Weiss offered the fairly typical definition of this type: 'A conservative is a person who hopes to preserve or restore some significant part of the political structures, social arrangements, economic relationships or cultural values of the past.' ${ }^{\text {It }}$ should be noted that, unlike Scruton, who only mentioned conservation, Weiss, who called the same thing 'preservation', added a second element, 'restoration'. It was the association of preservation (of what we have) and restoration (of what we have lost) that enabled him to run together traditionalism, conservatism, reaction and counterrevolution in his title. Weiss's book was a fairly idiosyncratic sketch of history. But even a serious and cautious scholar like Albert Hirschman in The Rhetoric of Reaction took it for granted that conservatism and reaction were the same thing. Corey Robin's more recent book The Reactionary Mind has followed the

3 Anthony Quinton, The Politics of Imperfection (London: Faber and Faber, 1978), 19.

4 Roger Scruton, A Dictionary of Political Thought (London: Pan, 1983), 90.

5 Ibid., 394-5.

6 Kieron O'Hara, Conservatism (London: Reaktion, 2011); Martin Beckstein, 'What Does It Mean to be a True Conservative?', Global Discourse 5 (2015), 4-21.

7 Mark Lilla, The Shipwrecked Mind: On Political Reaction (New York: New York Review Books, 2016), xii.

8 JohnWeiss, Conservatism in Europe 1770-1945:Traditionalism, Reaction and Counter-Revolution (London: Thames and Hudson, 1977), 7. 
same line. Robin says that he is concerned with 'the political ideas - variously called conservative, reactionary, revanchist, counterrevolutionary'. ${ }^{9}$ And he is explicit about the identification: 'I use the words conservative, reactionary and counterrevolutionary interchangeably'.10 Regarding Oakeshott's characterisation of conservatism, he comments: 'Oakeshott's view of the conservative ... is not an insight: it is a conceit.'11 And his reason for saying so is because he thinks, unlike Oakeshott, that there is a 'reactionary imperative that lies at the core of conservative doctrine. ${ }^{12}$

The disagreement is clear. Some writers, up to and including Mark Lilla in a book published in 2016, have declared that conservatism is not reaction. Others, up to and including Corey Robin in a book published in 2013, have declared that conservatism is reaction. In order to be clear about the exact difference between the two positions it is useful to express them in the same language. This is possible if I turn to the definition of conservatism recently put forward by Geoffrey Brennan and Alan Hamlin. They declare that conservatism 'is simply the explicit recognition of the normative status of the status quo.'13 This definition is interesting, since it uses a word not often used in discussions of conservatism, namely, 'normative'. A norm is a standard. Normative political theory is almost always liberal: that is, it uses intuitions or thought experiments to offer a set of standards by which we can judge our current practices. Those standards are meant to come from somewhere other than our practices, to avoid circularity. So it is interesting to have the suggestion that our current practices, or some elements of them, can be explicitly normative. Liberals would say this is circular. We need not worry about this overly, since critical or radical theorists often suggest that liberals themselves engage in the same circularity when they take their normative standards, whether consciously or not, from their current practices. ${ }^{14}$ Be that as it may, Brennan and Hamlin's definition is a rewriting of Oakeshott's definition and means the same thinga status quo conservatism.

We can use Brennan and Hamlin's definition as a template for a preliminary definition of reaction:

\footnotetext{
$9 \quad$ Corey Robin, The Reactionary Mind: Conservatism from Edmund Burke to Sarah Palin (Oxford: Oxford University Press, 2013), 4.

$10 \quad$ Ibid., 34.

11 Ibid., 47.

12 Ibid., 25 .

13 Geoffrey Brennan and Alan Hamlin, 'Analytic Conservatism', British Journal of Political Science 34 (2004), 675-691, at 676.

14 See, for this sort of criticism, Perry Anderson, Spectrum (London: Verso, 2005).
} 
If conservatism is simply the explicit recognition of the normative status of (some element of) the status quo,

Then reaction is the explicit recognition of the normative status of (some element of) the status quo ante.

It should be noted that I have not yet declared myself on whether conservatism is reaction or not. The indented proposition is conditional. What I have done is indicate under what condition it is reaction, and under what condition it is not.

In the next section I shall turn to conservatism. This is because although some define conservatism as status quo conservatism, some others do not. This clearly influences whatever is said about reaction. So we cannot understand reaction until we understand conservatism.

I shall try to be brief here, since I have written about conservatism at length elsewhere. ${ }^{15}$ There are probably three substantial views of the nature of conservatism which would make sense to everyone at a practical level.

The first is that conservatism is an abridgement or abstraction of the practices and understandings of those who call themselves conservatives. This was well articulated by Elie Kedourie: 'Conservatism ... is the outcome of activity in various circumstances and over a long period of the Conservative party, an abridgement, and so to speak a codification, of this activity. Conservatism follows and does not precede the existence of a Conservative party. It is a natural attempt by a body with a long continuous existence to articulate and make intelligible to itself its own character.' ${ }^{\prime 6}$ This is obviously true, and a good definition, but it is without specific content, and, of course, stops short of making intelligible the character of conservatism.

The second goes further, not by specifying a content for conservatism but by identifying it as a permanent inclination, tendency or disposition. As Oakeshott theorised it, it is the disposition to delight in the status quo, and as expressed in the terms used by Brennan and Hamlin, it is the disposition to

15 In James Alexander, 'The Contradiction of Conservatism', Government and Opposition 48 (2013), 594-616 and James Alexander, 'A Dialectical Definition of Conservatism', Philosophy 91 (2016), 215-232.

16 Elie Kedourie, 'Conservatism and the Conservative Party', in The Crossman Confessions and Other Essays (London: Mansell, 1984), 37-46, at 38. 
defend the status quo. This sort of view, like the first, avoids claiming that conservatism has any fixed content, ideals or principles. The disposition remains the same no matter how the status quo changes. One can obviously be conservative about something which conservatives of an earlier generation opposed. An alternative or adjusted theory of conservatism as a disposition would perhaps resemble our ordinary or common sense idea of conservatism if, as well as defending the status quo, it were also to involve defending the immediate status quo ante. But even this would have no fixed content.

The third view, it should be obvious, is therefore that conservatism has some sort of definite permanent content. ${ }^{17}$ It is more than an abridgement or abstraction, and more than a disposition, because it forms an absolute singular position. But what is it? The usual thing done in books of ideologies is to ask the question, fail to find a coherent answer, and instead list tradition, authority, hierarchy, and so on, before admitting that these are not always coherent. I think the incoherence is that of the scholar. The point is not that tradition, authority and hierarchy exist as components of conservatism now, though in the form of abstract, fragmentary and incoherent components. No: the point is that tradition, authority and hierarchy are supposed to have been coherent in the past, in a form which was not perfect and never taken to be perfect at the time. As time has passed, and some of that modus vivendi has been lost, whether deliberately or not, elements of what has been lost are seen to have been more valuable than anyone at the time was capable of stating consciously. They never needed to state it consciously since it was not under threat. Conservatism, in this sense, is not secular fragments of an ancien régime, but an idea of the ancien régime once it has passed, after the fact, in fact après le déluge.

Now, if we accept these three views of conservatism as plausible versions of what conservatism might mean, then we can see that the question of whether conservatism and reaction are associated depends not only on what we mean by reaction but on which of these meanings of conservatism is taken most seriously. Only the second view wholly and obviously excludes reaction. This is because status quo conservatism is a disposition to hold onto whatever one has

17 A famous example of this approach is Russell Kirk in The Conservative Mind: From Burke to Santayana (Chicago: H. Regnery Co., 1953), later republished as The Conservative Mind: From Burke to Eliot. It has been pointed out to me by David Corey that Corey Robin alluded to Kirk's title in his own title The Reactionary Mind: Conservatism from Edmund Burke to Sarah Palin, thus shifting what Kirk had considered to be 'conservatism' over into 'reaction', as well as adding a bathetic note in the descent from Santayana or Eliot to Palin. I notice that Robin has recently put out a second edition of his book, now perhaps predictably entitled The Reactionary Mind: From Edmund Burke to Donald Trump (Oxford University Press, 2017). 
already, and thus is not intrinsically reactionary, if by 'reactionary' we mean anything that is a reaction, or response, to something else. Though even in this case, this disposition, when it encounters other dispositions, involves reaction. If you take what I have already, if I want to hold onto it, I am likely to react to your act.

The simple point, that conservatism, even if defined in the most minimal way possible, cannot exclude reaction as soon as we imagine the conservative in any actual situation, was noticed by one of the earliest and greatest theorists of conservatism, Karl Mannheim, in 1925. 'The conservative', he wrote, 'only thinks systematically when he is moved to reaction, perhaps because he is forced to set up a system counter to that of the progressive, or because the process has progressed to a point where he has lost touch with the present state of things, so that he is compelled to intervene in order to reverse the process of history.'18 This almost seems to suggest that conservatism as Oakeshott describes it is a coherent position as long as we postulate a static world. As soon as we postulate a dynamic one, in which the status quo is threatened by an action, the conservative is a reactionary.

Samuel Huntington made a related point in 1957. He suggested that reaction emerges when the conservative is 'unsuccessful':

The unsuccessful conservative who remains attached to the ideals of his old ideational philosophy becomes a reactionary, i.e., a critic of existing society who wishes to recreate in the future an ideal which he assumes to have existed in the past. He is a radical. No valid distinction exists between 'change backward' and 'change forward'. Change is change; history neither retreats nor repeats; and all change is away from the status quo. As time passes, the ideal of the reactionary becomes less and less related to any actual society of the past. ${ }^{19}$

If we ask what Huntington meant by 'success', the answer seems to be 'changing as the status quo changes so that one's ideals are always exactly contemporary'. Anything other than that involves a flight forwards or backwards.

I shall write about conservatism henceforth as if it is only 'status quo conservatism'. This is not because I think conservatism is status quo conservatism, but because I think that to say so is in this context a useful simplification,

18 Karl Mannheim, Conservatism: A Contribution to the Sociology of Knowledge, eds. D. Kettler, V. Meja and N. Stehr (London: Routledge and Kegan Paul, 1986), 88-9.

19 Samuel Huntington, 'Conservatism as an Ideology', American Political Science Review 51 (1957), 454-73, at 46o. 
a shorthand which leaves things out which we can then bring back in later. It is perhaps worth saying that nowhere have I found an argument to explain why conservatism should be restricted to the status quo. My argument for the opposite view is very simple. It is this: 'Conservatism cannot be only holding onto the status quo or using the status quo as a normative standard. This is because the significant historical fact about conservatism is that it emerged after a revolution and is constituted by its coming after this revolution. A conservatism which only holds onto the status quo is a conservatism which pretends the revolution never happened and that we are still in the age of equipoise. In other words, it pretends that we are still traditionalists. But we cannot be traditionalists, for the reason that tradition is broken. After the revolution we have to consciously reconstruct traditions in a situation in which they have been threatened or destroyed; and conservatism is a part of this reconstruction. To understand conservatism, therefore, we have to understand the revolution that made it necessary.'

Now, it is true that this is a historical rather than philosophical argument. But if someone defends conservatism solely in terms of philosophy, all we can say is that they are offering us an abstraction, which is interesting, but fails even to recognise that such an abstraction was not available for anyone before the nineteenth century. And this fact cannot be irrelevant. Nonetheless I think we can use 'conservatism' to mean 'status quo conservatism' as long as we admit that we do so for the sake of simplification and with the recognition that conservatism, of course, usually means far more than this.

With this said, we can now turn to reaction.

\section{III \\ What is Reaction? Some Partial Answers}

I shall begin by looking at three books of note written on reaction in recent years. The first two associate conservatism and reaction, while the third does not, but each offers a unique vision of what reaction is.

Albert Hirschman's book, The Rhetoric of Reaction, though very readable, and in some ways the most thoughtful book on reaction, is, in the end, of hardly any constructive value at all. Hirschman's original reason for writing was presumably some sort of dislike of reaction, though he said he wanted to be fair to it. But his decision to characterise reaction as a sort of argument rather than a sort of mind, so far from enabling him to say what was wrong with reaction, led him to the observation that for every reactionary argument there was an equal and opposite progressive argument. For instance, he noted that for the progressive argument, 'Not to take the contemplated action will bring 
disastrous consequences', there was the reactionary argument, 'The contemplated action will bring disastrous consequences. ${ }^{20} \mathrm{He}$ admitted his failure to come up with an understanding of reaction with remarkable honesty. But there is no question that the book was unsatisfactory. It made no attempt to define reaction, which it treated only as a variant of extreme political rhetoric.

Corey Robin's more recent book The Reactionary Mind goes beyond rhetoric to suggest that reaction is a substantive political attitude. But it has to be said, frankly, that the argument is confused. On the one hand Robin wants to theorise reaction as part of the political battle between those with more power and those with less. He defines conservatism - and reaction, for, like Hirschman, he does not distinguish them - as the 'theoretical rendition' of the 'experience of having power'. ${ }^{21}$ 'It provides the most consistent and profound argument as to why the lower orders should not be allowed to exercise their independent will, why they should not be allowed to govern themselves or the polity. Submission is their first duty, agency, the prerogative of the elite. ${ }^{22}$ This is a static or unchanging vision of class conflict. But on the other hand he recognises that conservatism (or reaction) is dynamic. It is not simply the ideology of the ruling elite, or of those reacting against the ideologists of the subordinate classes: it is the ideology of those who have lost something they formerly had. 'The conservative ... speaks for a special type of victim: one who has lost something of value, as opposed to the wretched of the earth, whose chief complaint is that they never had anything to lose. ${ }^{23}$ Robin is right to say this, but it is a claim which sits awkwardly with his earlier claim that conservatism is the ideology of the ruling elite. The ideology of a ruling elite, and the ideology of a formerly ruling elite conscious of a loss of its power, are two very different things. Here, again, we encounter the distinction between status quo and status quo ante. But Robin seems to confuse them throughout his book.

One can see why Mark Lilla was so exasperated when he reviewed Robin's Reactionary Mind. ${ }^{24}$ In 2008 Lilla had written a manifesto for the study of reaction. 'We need', he wrote, 'to restore the term "reaction" to our vocabulary' Though there are many studies of revolution, there are hardly any of reaction. His major suggestion was that reactionaries, like revolutionaries, 'are obsessed

\footnotetext{
20 Albert O. Hirschman, The Rhetoric of Reaction: Perversity, Futility, Jeopardy (Cambridge, Mass.: Belknap Press, 1991), 167.

21 Robin, The Reactionary Mind, 4.

22 Ibid., 7.

23 Ibid., 58.

24 For Lilla's review see http://www/nybooks.com/articles/2012/o1/12/republicans-revolu tion/. For Robin's comment, and Lilla's reply see http://www/nybooks/articles/2012/o2/23/ reactionary-mind-exchange/.
} 
with ruptures in time, and see human experience as radically discontinuous'. But in case we thought that this meant revolution was the politics of the left and reaction the politics of the right, he added the qualification: 'Valences can switch: reaction is not a preserve of the right.' ${ }^{25}$ So it seemed as if he wanted to define reaction as any sort of inclination to reverse an abrupt political change. So far, so salutary. But his recent book The Shipwrecked Mind, though it repeats this point, has muddied the water by attempting to define reactionaries as 'antimodern cultural pessimists.' ${ }^{26}$ In contrast to Hirschman's treatment of reaction as a one-sided rhetorical style about change, and Robin's treatment of it as a one-sided view of power employed by the dominant side in a class struggle, Lilla suggests it is a one-sided view of time, a looking backwards manifest only as nostalgia. He treats reaction as a sort of neurosis by which some of us want to return to the past. Despite the force of his insight about the importance of time and revolution, his book is only a very slight contribution to the literature. He says he wants to take the reactionary seriously: he wants to understand his 'hopes and fears, his assumptions, his convictions, his blindness, and, yes, his insights. ${ }^{27}$ But the book is no more than a loose set of essays on miscellaneous intellectual figures like Leo Strauss, Eric Voegelin and Alain Badiou. The analysis does not get far beyond the metaphor of his title: 'The reactionary mind is a shipwrecked mind.28 This is an amusing metaphor, but limited. For the reactionary might well see himself more as Captain Bligh or Ben Gunn than Robinson Crusoe: a subject of mutiny or marooning rather than shipwreck. Or he might see himself as Captain Kidd: a pirate seizing the ships of the others. Even if nostalgia is an aspect of a reactionary temper, it cannot explain the ways in which reaction functions politically as criticism of the contemporary order. Reaction is nothing in politics if not concerned with the here and now. I might want to restore an order not because I want to go back in time or because I think 'things were better in the olden days', but because I think that our ancestors understood something rightly which we now understand wrongly. And then, clearly, reaction is a living, not a dead, attitude: for I can say this now: 'We are in the wrong; we have lost our way.'

Most political philosophers refuse to take conservatism seriously. And even those who do write about conservatism tend to ignore reaction. So it is to the credit of Hirschman, Robin and Lilla that they have discussed reaction. But

25 Mark Lilla, 'The Pleasures of Reaction', New Republic, 27 February 2008, https://newrepub lic.com/article/64827/the-pleasures-reaction.

26 Lilla, The Shipwrecked Mind, 39.

27 Ibid., $x v$.

28 Ibid., xiii. 
their writings, as I have shown, are limited in various ways, and for various reasons: but mostly because their dislike of reactionary politics has prevented them from considering it in the round. It is impossible to understand reaction if one refuses to see that it is as constructive in politics as it is destructive. In addition, each of these books would have been better if their authors had noticed the positions of their rivals.

So I think it is necessary to start again.

\section{Simple Reaction}

Reflection on the question 'What is reaction?' suggests that it has three major forms.

Before I examine them, it is worth saying something about the etymology of the word 'reaction'. The prefix 're-' is an interesting one, meaning both that an action is repeated, and that it is repealed or refuted. Since 'reaction' has never meant mere repetition of the same action, it follows that its meaning runs from an action which is a response to a prior action to an action which is intended to reverse or oppose a prior action. The word became common in the seventeenth century, especially after Newton's third law of motion (Actioni contrariam semper et cequalem esse reactionem) established the claim that to every action there is an equal and opposite reaction. In a strict sense, if we were to transpose this into politics, then we would have the claim that a political reaction is equal and opposite to some political action. But this is far too simple for politics, where reaction involves an element of time: so reaction is inevitably subsequent to action, rather than coincident, and so not exactly equal and opposite. But even then there is no point asking what 'reaction' is without asking what the particular 'action' which preceded it is. The action could be anything, emanating from the right or left or even centre of politics, or the height or depths of the hierarchy, or the centre or the periphery of the territorial order, and the reaction would have to correspond as an opposite. Though not a very common usage, it is possible to speak of reactionaries on the left. But this is only if we understand reaction to be something abstract, an abstract response to an abstract action.

This is a general point. Whatever reaction is depends on what we mean by action.

I want to distinguish three meanings of reaction in politics in terms of what we mean by action. The first meaning is relatively simple and, in fact, rather trivial. By action is meant 'any or every action'. Here, for every action, there is not so much an equal and opposite reaction-politics is not physics—but 
some sort of reaction, usually unequal and only, at most, opposed to the action in the sense that it is a deliberate counter to the action. ('I don't act', as a famous American film actor is reputed to have said, 'I react'.) This is a perfectly valid meaning of the word. But, clearly, we do not learn much about politics, or modern politics, if we limit ourselves to this meaning.

The second and third meanings of reaction are not so simple. They both involve the view that action is not just any action but some major action which changes the whole political order in such a way that a reaction against it would be a very significant thing. Between the original action and the reaction a great deal is at stake. But there is no one meaning here: there are two. I have to distinguish them with some care because I think that although one of them is a meaningful use of the word reaction, it is an abstraction from a particular use of the word, and that this particular use is the original and fundamental one- the one which enables us to make most sense of what the language of reaction entails. In order to explain the difference between these two meanings a digression is necessary. Yet it is, I think, a digression about a fundamentally important fact.

\section{v Homochronic and Heterochronic Concepts}

There is a phenomenon in the history of political thought which I think requires a name. It requires a name because though it is a phenomenon familiar to those who have laboured in the vineyard of history for a long time, it is one which has not received the attention it deserves by philosophers. This phenomenon concerns the fact that political concepts emerge in history at a particular time and yet, as soon as they emerge, they can be employed not only in the present, in order to characterise the situation in which those concepts have emerged, but can be used retrospectively to characterise past situations. In the eighteenth and nineteenth century, for instance, many political concepts emerged — revolution, imperialism, socialism, liberalism—which, in addition to being used to make sense of what was going on at the time, were also used to make sense of earlier times. This is usually called anachronism. ${ }^{29}$

Anachronism can mean, of course, simply anything which is out of its appropriate time, whether too early or too late, though the etymological root, the Greek anakhronismos, from ana-, 'backward', and khronos, 'time', indicates that

29 For a fascinating reflection on anachronism, see J.C.D. Clark, English Society, 1688-1832: Ideology, Social Structure and Political Practice during the Ancien Regime (Cambridge: Cambridge University Press, 1985), esp. 348. 
the original meaning was the use of a thing in an earlier time than was appropriate. So anachronism is a good word for the phenomenon of using a political concept such as 'imperialism' or 'radicalism' to describe a political phenomenon before the nineteenth century. The only problem with the word anachronism is that its meaning is pejorative: it carries the sense that something mistaken is being done. Plus it is hard to state clearly what the opposite of an anachronism is. If anachronism is considered a mistake, what is the name for the correct attitude? I shall propose two new words, homochronism and heterochronism, using the well-known prefixes in Greek, homo-, the same, and hetero-, other. A homochronic use of a term is a use of that term about a time when it was part of the established political language: for instance, the use of 'liberalism' to describe political activities or entities from the nineteenth century which were called liberal at the time. ${ }^{30}$ And a heterochronic use of a term is its use in a time in which it was not part of the established political language: for instance, the use of 'liberalism' to describe something from the eighteenth century or before.

In short:

A heterochronic use of a term is the general application of it to any or all times where it enables us to make sense of something.

A homochronic use of a term is the limitation of its use to the era of history in which it emerged and about which it was specifically intended to make sense.

The significance of this, here, is that 'reaction'-like many other words first used extensively in the nineteenth century — can be used heterochronically to analyse a universal feature of all political activity, or homochronically not only to analyse the language of modern politics but also to analyse the modern politics of which the emergence into language of this concept was an important feature.

This gives us the second and third meanings of reaction.

30 The heterochronic position was standard in the history of political thought before the 1960s and is still common in political theory. The homochronic position was famously advocated by Quentin Skinner, John Pocock and others. For more on this, see James Alexander, 'The Cambridge School, c. 1875 to 1975', History of Political Thought 37 (2016), $360-386$. 
The first meaning of reaction, as I have shown, is the particular meaning of reaction, which is not a political meaning but can be applied to politics. The second and third are distinctively political meanings of reaction, but the second is a generalised meaning, while the third is a singular meaning. The second meaning is more specific than the first, and the third is more specific than the second. The third is the most important meaning. This is because the second, heterochronic, sense of the word, is derived from the third, homochronic, sense of the word.

According to the first meaning, reaction is a word for any response to any action. According to the second meaning, reaction is the word for a response to some action which has involved a major change in the entire order: a response which opposes that change, and seeks to reverse it. This meaning of reaction is not trivial. But neither is it fundamental. Nonetheless, like the first meaning, it can be used to describe the response to any radical change. So it has no fixed place in politics: it can be a reaction on the left or on the right, a reaction of rulers or ruled, of kings, lords, armies, parliament, lawyers, intellectuals or populace. This is a now well-established meaning and has obvious plausibility: we know what it means when the word is used in any situation. But this should not confuse us. The reason the word has this general meaning is only because of an analogy between whatever is being discussed and the original situation in which reaction was spoken of as reaction.

According to the third meaning, political reaction is something even further specified. Whereas the second is a response of a certain significance to political actions of a certain significance, where both actions and reactions are general in nature, the third is a response to only one type of political action. This is the sort of political action which is particularly associated with the destruction of established traditions and the replacement of them by institutions and practices justified by enlightened ideas. So, here, reaction is opposed to revolution: it seeks to overturn not any major change but only those which have replaced the older order of, say, authority, hierarchy and religion with a newer order of, say, liberty, equality and fraternity. This is clearly the classic reaction of Joseph de Maistre, Friedrich von Gentz and Donoso Cortés. The revolution has taken place; the reactionary is opposed to it: and so the reactionary also opposes any further actions which further establish the principles established during the revolution or institutions and practices based on such principles. For instance, a reactionary opposed to the British Great Reform Act of 1832 would remain opposed to that even when arguing against the Reform Bills of 1866 or 1867. 
I want to distinguish, first, the most abstract meaning of reaction (where I react against this or that, so where a reaction is a response to any action), from, second, a general meaning of political reaction (where I react against some decisive political event, one which changes the entire order, by pointing to an older order as my point of orientation), and from, third, the specific meaning of political reaction (where I react against a decisive political event and point to an older as a point of orientation, but only where the decisive political event is a revolution whereby traditions are shattered and in their place an order is established which is justified by enlightened ideas alone).

This third meaning, not the second meaning, is the significant political meaning of reaction. Reaction is only reaction when it is opposed to action associated with revolution: and where revolution is the establishment of enlightened principles by which an order should be established. It follows that reaction is reaction against the action of revolution itself, and, in addition, reaction against any subsequent action which furthers the establishment of the order supposed to be built on the enlightened principles of the revolution. From all this it should be obvious that any discussion of reaction has to consider not only philosophy but history: and not history in the abstract, but the history of revolution, which here means the concepts associated with revolution.

In order to define reaction, therefore, we also need to define some adjacent concepts, namely, 'tradition', 'revolution' and 'progress', as well as 'conservatism'. I shall do this not on an ad hoc basis but as coherently as I can by attempting to relate all the concepts through the images that I think are generated whenever we use these concepts.

\section{The Images Implicit in the Concepts Associated with Revolution}

The key here is the distinction between the pre-revolutionary order and the post-revolutionary order. Let me follow J.C.D. Clark in calling the prerevolutionary order the ancien régime and Hannah Arendt in calling the postrevolutionary order the novus ordo saeclorum (literally, 'the new order of the ages'). ${ }^{31}$ This division of history is a simple division of the past into two, before and after. Now this implies a linear conception of history. But the acceptance of a linear conception of history was itself an achievement of the late eighteenth century, when both terms in italics were originally used and when we

31 For Clark, who was of course following long established European usage, see note 29. For Arendt, see note 35 . 
shifted from ancien régime to novus ordo saeclorum. The ancien régime understood the world in terms of a cycle. The maintenance of such cyclical traditions is, now, since we no longer take it for granted and need a name for it, 'traditionalism'. It is only when traditionalists began to understand that, no matter how carefully they preserved their traditions, they could not preserve an unbroken circle, that a linear conception of history emerged. Successive iterations of the cycle brought about changes, and change brought loss: the loss of things which could not be restored. This means that certain things were, as we like to say it, left behind. Once we begin to speak this way, the image of a circle has been replaced by that of a line running from past to future. The traditionalist may still pass on his traditions while thinking in terms of a linear history, but he has to face the possibility of a change that would mean the irrecoverable loss of all his traditions. If we imagine tradition as a line, then, if the traditionalist were successful, this would be an unbroken line. But if he were to fail, then the line would be broken. This is fairly easy to understand. Traditions may be replaced by other traditions for a variety of reasons. But the particular breaking of the line here is not that of simple replacement of one set of traditions by another but of the replacement of any set of traditions by a resolutely untraditional set of beliefs and standards. I shall call these 'enlightened principles' for short, since it should be obvious that I am referring particularly to the assault on all established traditions which is associated with the Enlightenment. And I shall define revolution as 'the establishment of the principle that order should be established only on enlightened principles'. I define it this way to emphasise the fact that revolution is not the realisation of those principles. Admittedly, it may at times involve the hope that 'the establishment of the principle that order should be established only on enlightened principles' is the same thing as 'the establishment of an order on those principles'. But revolution is only the first of these things. It is the rupture which divides the ancien régime from the novus ordo saeclorum. And it changes everything.

It changes everything - even though enlightened principles may exist in the ancien régime and even though traditions may survive somehow even in the novus ordo saeclorum. It changes everything because the traditionalist can no longer simply pass on his traditions in the old manner. As long as he could do so, he accepted the passage of time and, as it were, accompanied it, acting out his traditions and handing them across when appropriate. He did not attempt to interrupt time, force its pace, or retard its advance. He was passive in relation to time. But after the revolution, or once he has the idea of revolution in his mind (even if, strictly speaking, a revolution has not yet occurred), he has to be active, because it is the condition of all activity that it be active in relation to time. 
This is the principle of the novus ordo saeclorum. There is a rupture in tradition, so the old order of hierarchy, authority and religion is gone, and is replaced by novel enlightened ideals of liberty, equality and fraternity. Let this be understood: the 'traditionalist' is gone. And it is in this context that we have to distinguish 'progressives', 'conservatives' and 'reactionaries'. If revolution is 'the establishment of the principle that order should be established only on enlightened principles', then progress is 'the activity or process of establishing order on enlightened principles'. So a 'progressive' is someone who is actively 'advancing' into the future. He imagines that an order constructed on enlightened principles will exist at some unknown point in the future-even if it is, as Kant thought, an infinitely distant unknown point in the future-and that the imperative, therefore, is to act to achieve such an order. The image here is one of forcing time, of advancing or even accelerating into the future. As J.B. Bury put it in The Idea of Progress: 'It is based on an interpretation of history which regards men as slowly advancing - pedetemtim progedientes - in a definite and desirable direction and infers that this progress will continue indefinitely.'32 Or as Reinhart Koselleck put it in Futures Past: 'Freedom, progress, improvement suggest a world accelerating towards the future. 33

So much for the progressive. But what of the conservative and the reactionary? The major point I want to make is that there is a difference between the reactionary and conservative, once we define the conservative as a status quo conservative, as I have done, and once we understand the image of revolution as a break in a line. Revolution means that traditionalism is no longer possible. So the former traditionalist has a choice. Either he may attempt to restore as much of the old order as possible, or in terms of our image, go backwards rather than go forwards. In this case he is a reactionary. Or he may decide to accept the revaluation of values imposed by the revolution and attempt to live as much like the former traditionalist as is possible in the new enlightened conditions. In this case he is a conservative.

Another way of putting this distinction is that the conservative attempts to hold onto the form of traditionalism, while the reactionary attempts to hold onto the content of traditionalism. By this I mean that both follow the imposition of a linear scheme and a rupture in that linearity. After the rupture, conservatives try to live as much as possible in the changed conditions of the novus ordo saeclorum as traditionalists did in the ancien régime. They live like

32 J.B. Bury, The Idea of Progress: An Inquiry into Its Origins and Growth (London: Macmillan, 1920), 5 .

33 Reinhart Koselleck, Futures Past: On the Semantics of Historical Time (Camb. Mass.: MIT Press, 1984), 7 . 
traditionalists as much as possible, but with traditions of a different content, an enlightened content. They try to ignore the rupture, and in so doing eventually come around to defending only the status quo. On the other hand, reactionaries, after the rupture, change their tactics. Unlike traditionalists, who were at ease in the ancien régime, and conservatives, who try to be at ease in the novus ordo saeclorum, reactionaries remain defiantly ill at ease about the changed conditions of the novus ordo saeclorum and deliberately adopt an attitude which gestures at restoring as much of the old traditions as possible even though they know that it is absurd to 'go backwards'. (They justify this by observing, what progressives refuse to recognise, that it is also absurd to 'go forwards'.) They want to preserve the content of the old traditions, but, in order to do so, have to abandon traditionalism.

The shift into modernity, the shift from the ancien régime to the novus ordo saeclorum, marks the end of the old traditions. There will of course be new traditions - some 'invented', some emerging spontaneously — but these will be traditions of enlightened, progressive or ideological politics, of a politics transformed by abstractions. And suddenly everything is set in motion and broken up into pieces. The revolution is 'the substitution of becoming for being, the relative for the absolute, dynamic movement for dogmatic immobility'. ${ }^{34}$ 'History suddenly begins anew'. ${ }^{35}$ There is no longer a 'sense of the cumulation of experience'. Instead there are only 'abstract principles' or 'ideologies' which at best are nothing other than 'abridgements of a tradition'. ${ }^{36}$ Tradition is broken into fragments so it can survive in these novel, dynamic conditions. And this enables us to clarify the distinction between reactionary and conservative yet again. Abridgement is the cutting down of something originally complete. We can cut out either the continuity or the content of tradition: we cannot have both. The conservative- the status quo conservative-cuts out the content and keeps the continuity; the reactionary cuts out the continuity and keeps the content. Ideally, it should be noted, both would keep both. (This is why it is correct to say reactionaries and conservatives are cut from the same cloth. They are both traditionalists in an order no longer traditional.) But they cannot take both. And so they differ in which part they take. (This is why it is also correct to say that they fashion different clothes from the same cloth.) Seen this way, the conservative has no tradition he could not abandon, since he abandons the idea that traditions are a ground. For him the only criterion

34 John Morley, Recollections, (London: Macmillan, 1917), Vol. I, 71-2.

35 Hannah Arendt, On Revolution (London: Penguin, 1990), 28.

36 Michael Oakeshott, 'Rationalism in Politics', in Oakeshott, Rationalism in Politics and Other Essays, 5-42 at 6. 
is the currently existing status quo. So his politics, as critics of conservatism always say, is the politics of resistance, inertia, and sometimes, as John Stuart Mill famously said, stupidity. The reactionary is very different, since he holds onto something in the past. As time goes on, he may seem more and more absurd to anyone who, like the progressive, believes in the 'forward movement' of history. But, as many critics of reaction have observed, the reactionary, unlike the conservative, remains a radical.

\section{The Specific Meaning of Reaction}

The specific meaning of reaction, as I have defined it here, follows from a specific, though rarely stated, meaning of action. This is the sort of action which the reactionary reacts against. It gives us a historical as well as philosophical definition of reaction, since, at least in our history, action in this sense has only happened once.

\section{What is action?}

Action is what establishes a breach in tradition, a breach called revolution, and does so by insisting that from now on all order will be justified by abstract enlightened principles. Derivatively, it is also any action (in the sense of continuous activity) which comes after the revolution and which continues to act on those principles in order to complete the construction of an order only justified by those principles.

\section{So what is reaction?}

Reaction, in the third, or specific sense, therefore has two related meanings. It can refer to action that is intended to overcome the breach with tradition called revolution and, derivatively, it can also refer to action that is opposed to the construction of an order based on the principles which the revolution established.

Now, what should be noticed here is that this is a definition of reaction which is not simply about extreme political rhetoric (Hirschman), or about a ruling ideology in a class struggle (Robin) or nostalgia (Lilla). Reaction may involve the use of extreme political rhetoric, though it also may not. It may be a ruling ideology, but it also may not. It may involve nostalgia, but it may not. In one sense, though it should be obvious that the analysis here is closest to Lilla's in laying emphasis on the time element, his characterisation is the least persuasive, since at least Hirschman and Robin try to account for the force of reaction in contemporary politics, which he does not. For Lilla, reaction is fundamentally mistaken. Against this, I would argue that reaction is not a political attitude which is fundamentally mistaken because it is lost in the past but is 
a political attitude which is very firmly focused on the present, and which uses historical knowledge in order to satirise the loss of knowledge in the contemporary world.

I have suggested that reaction opposes two things: it continues to oppose in the present a rupture which occurred in the past, no matter how paradoxical that seems, and it also opposes in the present the perpetuation of the ideals established as normative after that rupture. The reactionary in some sense or other seeks restoration of an older order. But he is not simply nostalgic: he is not simply lamenting over the image of Charles I on the scaffold: rather, he is turning such a lament into a political cry of some sort. This is where Lilla goes wrong. The reactionary cannot be lost in the past, for then he would not be a reactionary, but an antiquarian. And there is another point. Even the desire for restoration is not, or not always, an actual intention to restore an older order. No politician can remain an impossibilist. The reactionary may admit that restoration is impossible, and yet remain a reactionary in the sense of being opposed to the revolution. The reactionary may say, 'In so far as I am acting politically in the present, I, like the status quo conservative, must trim, must act in a latitudinarian manner, must accept the political standards of the day, even if these are fundamentally antithetical to my own deepest views; however, I want to find a way to express my fundamental commitment to standards which are not of this world.' This may take the reactionary as far as some sort of doctrine of eternity - an escape from temporality altogether. Michael Oakeshott commented that, for Joseph de Maistre, 'the politics of time [were] intelligible only in the context of the politics of eternity. ${ }^{\prime 3}$ In the same way, Maurice Cowling wrote that even though he advocated conservatism when it came to politics, conservatism was not 'secular truth' for the reason that the only truth of any importance was the truth of Christianity. ${ }^{38}$ The reactionary, then, may believe in eternity. But, if so, he associates eternity with an earlier time. Is this a contradiction? No, because the reactionary maintains that eternity, or the belief in eternity, was lost at some point in the past.

Cowling was a Cambridge historian who attracted critical attention in the late twentieth century for defending a conservative position. At times he admitted his position was reactionary; at other times not. In 1985 another historian, Paul Addison, reviewed the second volume of Cowling's Religion and Public Doctrine in Modern England. In the review Addison claimed that Cowling was a

37 Michael Oakeshott, The Vocabulary of a Modern European State, ed. Luke O'Sullivan (Exeter: Imprint Academic, 2008), 202.

38 Maurice Cowling, Mill and Liberalism 2nd edition (Cambridge: Cambridge University Press, 1990), xxxi. 
reactionary. Cowling responded: 'It is true that in writing about religion I have adopted Laudian, Tractarian and Anglican postures and analyses and have pointed them accusingly at the postures and analyses of modern secularism. I have done this, however, not as a method of self-disclosure (except about the distant past), but as a form of heuristic satire....' He then claimed that he was 'not really' a reactionary. ${ }^{39}$ Addison would not accept this, though he admitted that the picture was complicated:

As a reactionary, he measures the present by the standards of the past and finds the present corrupt. As a realist, he accepts that for the time being life must be lived according to the rules of a secularised liberal society he despises. As a relativist, he recognises that his own ideas have no more claim to objective truth than anyone else's. If I had wished to write an unfair review, I would have argued that these three opinions cancel one another out. But I believe Mr Cowling to be a coherent reactionary who admits with remarkable honesty the difficulties inherent in his position. ${ }^{40}$

Now, this is very interesting for several reasons. We may leave aside Cowling's denial that he was reactionary. This is a label that anyone might want to reject if used against them. There were two interesting points made: one by Cowling, one by Addison. The first was that reaction might be more about 'satire' than 'nostalgia'. The second was that a reactionary 'judges the present by the standards of the past and finds it corrupt'. Both points emphasise the fact that reaction is a political attitude focused on the present.

Addison's observation can be used as a template to clarify the differences between the positions I have discussed so far in this article:

A traditionalist judges the present by the standards of the past and finds it justified.

A progressive judges the present by the standards of the future and finds it corrupt.

A reactionary judges the present by the standards of the past and finds it corrupt.

A conservative judges the present by the standards of the present and finds it justified.

39 Maurice Cowling, letter, London Review of Books Vol. 8 no. 19 (6 Nov 1986), retrieved from https://www.lrb.co.uk/vo8/n19/letters.

40 Paul Addison, letter, London Review of Books Vol. 8 no. 22 (18 Dec 1986), retrieved from https://www.lrb.co.uk/vo8/n22/letters. 
Considered as a contribution to contemporary politics, Cowling offers the useful hint that the best way to understand the reactionary is as a satirist, using the standards of the past to expose the empty standards of the present. Against the progressive, he does not simply want to fall back on the situational, inertial, dispositional arguments of the conservative, and then eventually capitulate, as status quo conservatives always do when the status quo changes. Instead, he wants to oppose to the certainties of the progressive some other certainties: against the abstract and ideal certainties of the philosopher he brings the concrete and actual certainties of the historian. This is the point: he uses the past (perhaps I should write 'past') as a weapon against the present, in equal opposition to the progressive who uses the future (perhaps I should write 'future') as a weapon against the present.

With this said, let us consider in detail what reactionary politics entails. So far I have suggested that it includes the restoration of an older order, resistance to contemporary progressive doctrines, and the continued use of older standards to judge the contemporary order. Let me summarise these three elements:

Reaction is ultimately the politics of the restoration of the ancien régime in the changed conditions of the novus ordo saeclorum, that is, the attempt to overturn the revolution by which the principle was established that order could only be established on enlightened principles.

Then reaction is the politics of continuing to resist the doctrines of progressives who attempt to build on the revolutionary principle by completing the establishment of that order.

And finally reaction is the politics of criticism of the novus ordo saeclorum by the critical imposition of the standards of the ancien régime on the contemporary order, especially by the use of historical knowledge to satirise and criticise the flaws and limits of contemporary politics.

It is, at its root, and in theory, counter-revolutionary, but in practice it often shares many strategies with those of status quo conservatism, especially in terms of resisting progressive politics. And yet, unlike the status quo conservative, the reactionary remains radically critical of the status quo, a status quo which the conservative has accepted.

Reaction is therefore necessary. If the conservative accepts the revolutionary principle that order should be established only on enlightened principles, but cannot - without ceasing to be a conservative-act on the basis of enlightened principles, then the conservative is in a very difficult position. Most conservatives overcome this by continual compromise. But for the reactionary 
this is a form of trimming or latitudinarianism which makes the conservative as much an enemy as the progressive. And then the progressive has simply won the argument. And continues to think he has done so by saying things like "That is out of date', 'We cannot go backwards' and 'You cannot ignore the march of history'. An enlightened politics is based on overcoming the singularity of traditions, of generating some sort of liberal consensus. Conservatives, who accept the principle, are forced to operate within the liberal consensus, and, as John Stuart Mill put it, think 'themselves into the mental position of those who think differently from them'. ${ }^{41}$ The reactionary is not so forced. The reactionary agrees with Samuel Johnson, who said, 'To treat your opponent with respect is to give him an advantage to which he is not entitled.42 Or with G.K. Chesterton: 'No one knew better than Chesterton that the best way to expose the arbitrariness of the principles of the high-minded was, whether having any serious commitment to them or not, provocatively to flaunt an opposite set.43 Derision and the deliberate maintenance of a reactionary principle in the face of an enlightened one: these are two of the major modes of the reactionary.

Yet it should be remembered that the reactionary only says 'No!' because the progressive says 'Yes!' And that the reactionary has to affront the progressive because the progressive is inclined to think that by saying 'Yes!' all difficulties have ended and the argument has been won.

\section{Conclusion}

Let me summarise the entire argument:

Reaction may be (in increasing order of specification):

1. a response to any action,

2. a response to an action which makes a major change in the order,

3. a response to an action which makes a major change in the order by supplanting a traditional order with an order consciously founded on enlightened principles,

and the third of these-reaction proper (the homochronic meaning of reaction) — has several aspects. It may be:

41 J.S. Mill, On Liberty and Utilitarianism (London: Everyman Library, 1992), 37 (from ch. 2).

42 As quoted by John Morley, 'John Stuart Mill', in Miscellanies: Fourth Series (London: Macmillan, 1908), 145-70, at 163 .

43 Maurice Cowling, The Nature and Limits of Political Science (Cambridge: Cambridge University Press, 1963), 87. 
3a. reaction in the form of an attempt to overturn the action which supplanted the traditional order (where reaction clearly differs from status quo conservatism),

3b. reaction in the form of attempts to resist any further attempts to entrench an order founded on enlightened principles (where reaction clearly has much in common with status quo conservatism),

3c. reaction in the form of the maintenance of critical judgement of the contemporary order in terms not of enlightened but of older traditional views (where, again, reaction differs from status quo conservatism).

I have sketched the way in which reaction contrasts and compares with status quo conservatism. But, equally clearly, though reaction and status quo conservatism are two different things, I think that reaction in this third sense is an element in a status quo ante conservatism. As I have suggested, it would not be a mistake to define reaction as status quo ante conservatism, as long as it is clear that the status quo ante is the one which existed before the revolution by which a traditional order was supplanted by a supposedly enlightened one.

In sum, reaction is distinct from conservatism, if conservatism is solely status quo conservatism; but if conservatism is more than status quo conservatism, then reaction is clearly an important element of conservatism.

\section{Acknowledgements}

I am indebted to Frank Ankersmit, David Corey, John Dunn, Ian Harris, Ian Robinson and Gulsen Seven for consideration of and criticism of this article: indeed for reacting to reaction. 'I would always rather listen to the opponent of my favourite opinions, if he is worth anything himself, than to a defender of them.' (Friedrich von Gentz in 1791-ironically, as it would later seem, since he was referring to Edmund Burke's Reflections on the Revolution in France.) 